\title{
Takotsubo syndrome - fatal prognosis of patients with low body mass index in 5-year follow-up
}

\author{
Malgorzata Zalewska-Adamiec ${ }^{1}$, Jolanta Malyszko², Hanna Bachórzewska-Gajewska ${ }^{1}$, \\ Anna Tomaszuk-Kazberuk ${ }^{3}$, Sławomir J. Dobrzycki ${ }^{1}$
}

\begin{abstract}
${ }^{1}$ Department of Invasive Cardiology, Medical University of Bialystok, Bialystok, Poland ${ }^{2}$ Department of Nephrology, Dialysis and Internal Medicine, Warsaw Medical University, Warsaw, Poland

${ }^{3}$ Department of Cardiology, Medical University of Bialystok, Bialystok, Poland
\end{abstract}

Submitted: 14 February 2019

Accepted: 2 June 2019

Arch Med Sci 2020; 16 (2): 282-288

DOI: https://doi.org/10.5114/aoms.2019.87082

Copyright $\odot 2019$ Termedia \& Banach

\section{Abstract}

Introduction: The clinical courses of takotsubo syndrome (TS) and of acute coronary syndromes (ACS) seem to be very similar. However, there is limited knowledge about risk factors of poor outcomes. Low body mass index worsens the prognosis of patients with cardiovascular diseases, especially those undergoing surgical treatment. The aim of the study was to evaluate the influence of the body mass index (BMI) on the prognosis in patients diagnosed with TS.

Material and methods: Eighty patients aged 15-89 (mean: 67.9 years), 74 women and 6 men with TS diagnosis according to Mayo Clinic diagnostic criteria were divided into 3 groups: low body mass (BMI $<18.5 \mathrm{~kg} / \mathrm{m}^{2}$ ), normal body mass $\left(18.5 \geq \mathrm{BMI}<25 \mathrm{~kg} / \mathrm{m}^{2}\right)$ and excessive body mass $\left(\mathrm{BMI} \geq 25 \mathrm{~kg} / \mathrm{m}^{2}\right)$. Results: Patients with low BMI were older, but with less prevalent risk factors such as hypertension, hypercholesterolemia and positive family history of coronary artery disease and more frequent risk factors such as cigarette smoking, chronic obstructive pulmonary disease (COPD), depressive and anxiety disorders as well as malignancy. They also had higher haemoglobin, lower troponin, creatine kinase, C-reactive protein and lipid fractions. The highest annual, 3-year and 5-year mortality was observed in the group with $\mathrm{BMI}<18.5 \mathrm{~kg} / \mathrm{m}^{2}$. None of the patients with low BMI survived the 5 -year follow-up period ( $100 \%$ vs. $25 \%$ vs. $15.2 \% ; p<0.0001)$. In group III, mortality among overweight patients $\left(25 \geq \mathrm{BMI}<30 \mathrm{~kg} / \mathrm{m}^{2}\right)$ was $8.3 \%$, and in obese people $\left(\mathrm{BMI} \geq 30 \mathrm{~kg} / \mathrm{m}^{2}\right) 1$ out 5 patients died during follow-up.

Conclusions: The majority of typical cardiovascular risk factors are less frequently observed in patients with TS and low body mass. Early prognosis for TS patients and low BMI is relatively favourable, whereas the 5-year follow-up is associated with extremely high mortality. Overweight patients have the best prognosis in the long-term follow-up.

Key words: takotsubo syndrome, body mass index, mortality.

\section{Introduction}

Takotsubo syndrome (TS) is a transient systolic dysfunction of the left ventricle, which is caused by stress. This particular syndrome is most frequently observed in postmenopausal women with minimal cardiovascular risk factors and the clinical course resembles acute coronary syndromes [1-3].

\author{
Corresponding author: \\ Prof. Jolanta Malyszko \\ $\mathrm{MD}, \mathrm{PhD}$ \\ Department \\ of Nephrology, \\ Dialysis and \\ Internal Medicine \\ Warsaw Medical \\ University \\ 1 a Banacha St \\ 02-097 Warsaw, Poland \\ Phone: +48 225992658 \\ E-mail: jolmal@poczta.onet.pl
}


Takotsubo syndrome was first described by Sato et al., in 1990 [4]. For many years it was believed that the prognosis of patients with takotsubo was good. Nonetheless, subsequent follow-up studies revealed the possibility of severe complications that may occur during the early stage of the disease. Both early and late mortality is compared to mortality reported in non-ST segment elevation myocardial infarction (NSTEMI). Despite numerous clinical trials, the etiology of TS remains not entirely known, similarly to factors posing an influence on the prognosis [5-7].

The body mass index (BMI) is a well-recognized parameter used to evaluate nutrition disorders in adults. In our previous publication low BMI appeared to be a significant death risk factor during the 3-year observation of patients with TS, which prompted the authors to perform additional analyses [7].

The aim of this study was to assess the impact of body mass index on early and long-term prognosis in patients with TS.

\section{Material and methods}

During a 5-year period (2008-2012), TS was diagnosed in 101 patients treated in four invasive cardiology centres in Podlasie Province. Eighty patients $(n=80)$ with TTS diagnosis confirmed according to Mayo Clinic diagnostic criteria in force at the time and with an estimated BMI value were enrolled in the retrospective study [8]:

- transient hypokinesis, akinesis, or dyskinesis of the left ventricular mid-segments with or without apical involvement; the regional wall motion abnormalities extend beyond a single epicardial vascular distribution; a stressful trigger is often, but not always present,

- absence of obstructive coronary disease or angiographic evidence of acute plaque rupture,

- new electrocardiographic abnormalities (either ST-segment elevation and/or T-wave inversion) or modest elevation in cardiac troponin,

- absence of pheochromocytoma and myocarditis.

The negative medical history and the lack of clinical symptoms of myocarditis and pheochromocytoma have made it possible to recognize takotsubo.

Patients who were diagnosed with TS despite the presence of significant atherosclerotic lesions found in coronarography $(n=6)$, as well as 15 patients with unknown body mass, were excluded from the study.

Body mass index was calculated according to the Quetelet's equation: body mass $(\mathrm{kg}) /$ height $(\mathrm{m})^{2}$.

Patients were divided into 3 groups: group I (GI) $-6(7.5 \%)$ patients with low body mass (BMI $<18.5 \mathrm{~kg} / \mathrm{m}^{2}$ ), group II (GII) - 28 (35.0\%) people with normal body mass $\left(18.5 \geq \mathrm{BMI}<25 \mathrm{~kg} / \mathrm{m}^{2}\right)$ and group III (GIII) - 46 (57.5\%) patients with excessive body mass (BMI $\geq 25 \mathrm{~kg} / \mathrm{m}^{2}$ ), including 10 obese patients with $\mathrm{BMI} \geq 30 \mathrm{~kg} / \mathrm{m}^{2}$. Figure 1 shows the BMI distribution in the takotsubo group.

The observational study was performed on average after 5.2 years based on the PESEL (personal identity number) register obtained from the Ministry of Interior and Administration. Mortality, regardless of the cause, stood as the main endpoint.

\section{Statistical analysis}

The obtained data were then analysed statistically. Student's t-test and the Mann-Whitney $U$ test were used to compare quantitative data, and the $\chi^{2}$ test along with Fisher's test were used for qualitative data. All 3 groups of patients were compared in pairs. In the analysis of multiple comparisons, the Bonferroni correction was adopted. Survival analysis was conducted with the Kaplan-Meier estimator. Apart from factors that showed significant differences between groups, multivariate analysis, which was performed based on logistic regression method, focused on possible factors of considerable prognostic significance in patients with a history of acute coronary syndromes. Multivariate logistic regression analysis was carried out using the stepwise method. $P<0.05$ was assumed as a statistically significant value. The Statistica 13.1 program was used to perform statistical analysis.

\section{Results}

The study included 80 patients aged 15-89 (mean: 67.9 years), 74 women and 6 men. Women accounted for $92.5 \%$ of the patients with takotsubo. There were no significant differences in the number of men and women in groups with low, normal and excessive BMI. Comparison of demo-

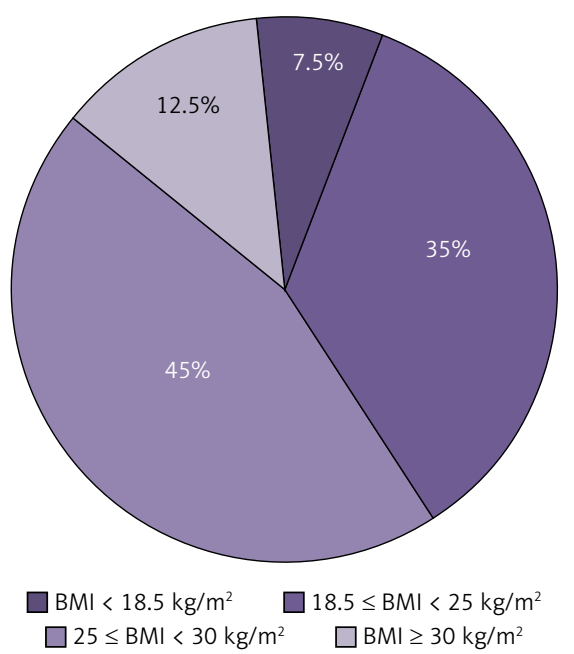

Figure 1. Distribution of $\mathrm{BMI}$ in takotsubo group $(n=80)$ 
Table I. Comparison of 3 groups of patients with takotsubo syndrome $(n=80)$

\begin{tabular}{|c|c|c|c|c|c|c|}
\hline Parameter & $\begin{array}{c}\text { Group I } \\
\text { BMI }<18.5 \\
\mathrm{~kg} / \mathrm{m}^{2} \\
n=6(\mathrm{SD}) \\
N(\%)\end{array}$ & $\begin{array}{c}\text { Group II } \\
18.5 \geq \mathrm{BMI} \\
<25 \mathrm{~kg} / \mathrm{m}^{2} \\
n=28(\mathrm{SD}) \\
N(\%)\end{array}$ & $\begin{array}{c}\text { Group III } \\
\text { BMI } \geq 25 \\
\mathrm{~kg} / \mathrm{m}^{2} \\
n=46(\mathrm{SD}) \\
N(\%)\end{array}$ & $\begin{array}{l}P \text {-value } \\
\text { GI vs. GII }\end{array}$ & $\begin{array}{l}P \text {-value } \\
\text { GI vs. GIII }\end{array}$ & $\begin{array}{l}P \text {-value } \\
\text { GII vs. GIII }\end{array}$ \\
\hline \multicolumn{7}{|c|}{ Clinical and demographic characteristics: } \\
\hline Age [years] & $76.3(5.7)$ & $67.6(15.8)$ & $67.0(12.1)$ & 0.0309 & 0.0081 & 0.959 \\
\hline Female sex (\%) & $5(83.3)$ & $26(92.9)$ & $43(93.5)$ & 0.451 & 0.377 & 0.920 \\
\hline Body mass index (BMI) $\left[\mathrm{kg} / \mathrm{m}^{2}\right]$ & 17.2 & 22.4 & 29.1 & - & - & - \\
\hline History of malignancy (\%) & $2(33.3)$ & $2(7.1)$ & $0(0.0)$ & 0.071 & $<0.001$ & 0.066 \\
\hline History of hypertension (\%) & $3(50.0)$ & $15(53.6)$ & $32(69.6)$ & 0.872 & 0.335 & 0.165 \\
\hline Hyperlipidemia (\%) & $1(16.7)$ & $11(39.3)$ & $19(41.3)$ & 0.293 & 0.244 & 0.865 \\
\hline Smoking (\%) & $2(33.3)$ & $5(17.9)$ & $18(23.9)$ & 0.397 & 0.616 & 0.543 \\
\hline $\begin{array}{l}\text { Family history of coronary artery } \\
\text { disease (\%) }\end{array}$ & $0(0.0)$ & $3(10.7)$ & $12(26.1)$ & 0.401 & 0.153 & 0.110 \\
\hline Diabetes mellitus (\%) & $1(16.7)$ & $0(0.0)$ & $11(23.9)$ & 0.028 & 0.693 & 0.005 \\
\hline Anxiety/depression (\%) & $2(33.3)$ & $2(7.1)$ & $4(8.7)$ & 0.076 & 0.071 & 0.811 \\
\hline Thyroid disorders (\%) & $1(16.7)$ & $6(21.4)$ & $13(28.3)$ & 0.796 & 0.547 & 0.510 \\
\hline Chronic kidney disease (\%) & $2(33.3)$ & $2(7.1)$ & $6(13.0)$ & 0.076 & 0.207 & 0.404 \\
\hline COPD (\%) & $3(50.0)$ & $4(14.3)$ & $3(6.5)$ & 0.049 & 0.0017 & 0.267 \\
\hline \multicolumn{7}{|c|}{ Diagnostic tests (echocardiography, coronarography, ECG): } \\
\hline $\begin{array}{l}\text { Left ventricular ejection fraction } \\
\text { on admission (\%) }\end{array}$ & $38.2(6.0)$ & $38.9(7.1)$ & $40.1(10.5)$ & 0.808 & 0.528 & 0.560 \\
\hline $\begin{array}{l}\text { No atherosclerotic changes in } \\
\text { coronary arteries* }(\%)\end{array}$ & $2(33.3)$ & $13(46.4)$ & $20(43.5)$ & 0.557 & 0.634 & 0.807 \\
\hline Insignificant stenoses**(\%) & $4(66.7)$ & $15(53.6)$ & $26(56.5)$ & 0.557 & 0.634 & 0.807 \\
\hline ECG - ST elevation (\%) & $6(100.0)$ & $19(67.9)$ & $30(65.2)$ & 0.105 & 0.082 & 0.811 \\
\hline QT on admission [ms] & $350.0(22.7)$ & $410.9(55.8)$ & $412.3(46.8)$ & 0.0003 & 0.0002 & 0.912 \\
\hline QTc on admission [ms] & $452.3(16.7)$ & $464.7(37.7)$ & $470.6(41.2)$ & 0.225 & 0.063 & 0.530 \\
\hline QT after a few days ${ }^{* * *}[\mathrm{~ms}]$ & $444.0(44.0)$ & $457.0(53.7)$ & $440.9(57.6)$ & 0.546 & 0.882 & 0.228 \\
\hline QTc after a few days ${ }^{* * *}[\mathrm{~ms}]$ & $496.7(18.5)$ & $\begin{array}{c}460.5 \\
(130.3)\end{array}$ & $476.8(44.8)$ & 0.170 & 0.067 & 0.527 \\
\hline \multicolumn{7}{|l|}{ Laboratory parameters: } \\
\hline Haemoglobin [mg/dl] & $14.2(3.1)$ & $12.8(1.2)$ & $13.4(1.6)$ & 0.202 & 0.228 & 0.038 \\
\hline Erythrocytes $\left[\times 10^{6} / \mu \mathrm{l}\right]$ & $4.9(1.2)$ & $4.3(0.5)$ & $4.5(0.6)$ & 0.311 & 0.530 & 0.066 \\
\hline Haematocrit (\%) & $41.9(9.2)$ & $38.2(3.8)$ & $39.4(6.9)$ & 0.370 & 0.537 & 0.338 \\
\hline Leukocytes $\left[\times 10^{3} / \mu \mathrm{l}\right]$ & $12.1(5.8)$ & $7.9(2.3)$ & $10.0(3.9)$ & 0.1429 & 0.4289 & 0.0051 \\
\hline Creatinine $[\mathrm{mg} / \mathrm{dl}]$ & $0.91(0.29)$ & $0.85(0.28)$ & $0.92(0.42)$ & 0.657 & 0.942 & 0.393 \\
\hline eGFR MDRD $\left[\mathrm{m} / \mathrm{min} / 1.72 \mathrm{~m}^{2}\right]$ & $70.9(23.8)$ & $75.8(24.2)$ & $72.6(25.7)$ & 0.662 & 0.875 & 0.592 \\
\hline CK [IU/I] & $156.5(97.9)$ & $\begin{array}{c}358.3 \\
(450.5)\end{array}$ & $\begin{array}{c}580.6 \\
(1263.4)\end{array}$ & 0.026 & 0.027 & 0.282 \\
\hline $\begin{array}{l}\text { Troponin (significant increase) } \\
(\%)\end{array}$ & $3(50.0)$ & $27(96.4)$ & $44(95.7)$ & 0.0013 & 0.0003 & 0.882 \\
\hline
\end{tabular}


Table I. Cont.

\begin{tabular}{|c|c|c|c|c|c|c|}
\hline Parameter & $\begin{array}{c}\text { Group I } \\
\text { BMI }<18.5 \\
\mathrm{~kg} / \mathrm{m}^{2} \\
n=6(\mathrm{SD}) \\
N(\%)\end{array}$ & $\begin{array}{c}\text { Group II } \\
18.5 \geq \mathrm{BMI} \\
<25 \mathrm{~kg} / \mathrm{m}^{2} \\
n=28(\mathrm{SD}) \\
N(\%)\end{array}$ & $\begin{array}{c}\text { Group III } \\
\text { BMI } \geq 25 \\
\mathrm{~kg} / \mathrm{m}^{2} \\
n=46(\mathrm{SD}) \\
N(\%)\end{array}$ & $\begin{array}{l}P \text {-value } \\
\text { Gl vs. GII }\end{array}$ & $\begin{array}{l}P \text {-value } \\
\text { GI vs. GIII }\end{array}$ & $\begin{array}{l}P \text {-value } \\
\text { GII vs. GIII }\end{array}$ \\
\hline $\begin{array}{l}\text { Troponin - mean concentration } \\
{[\mathrm{ng} / \mathrm{ml}]}\end{array}$ & $1.09(0.99)$ & $6.16(17.98)$ & $5.15(8.35)$ & 0.150 & 0.0029 & 0.781 \\
\hline Total cholesterol [mg/dl] & $165.2(30.9)$ & $189.6(38.1)$ & $182.4(45.4)$ & 0.131 & 0.262 & 0.466 \\
\hline $\mathrm{LDL}[\mathrm{mg} / \mathrm{dl}]$ & $96.3(18.8)$ & $115.9(33.2)$ & $113.1(43.1)$ & 0.071 & 0.115 & 0.754 \\
\hline $\mathrm{HDL}[\mathrm{mg} / \mathrm{dl}]$ & $51.6(17.8)$ & $56.7(17.0)$ & $49.3(17.3)$ & 0.541 & 0.775 & 0.076 \\
\hline Triglycerides [mg/dl] & $70.1(22.5)$ & $88.9(35.6)$ & $106.6(60.8)$ & 0.125 & 0.011 & 0.120 \\
\hline $\mathrm{CRP}[\mathrm{mg} / \mathrm{l}]$ & $11.74(7.7)$ & $26.5(30.7)$ & $38.7(65.8)$ & 0.032 & 0.0109 & 0.284 \\
\hline \multicolumn{7}{|l|}{ Clinical course and mortality: } \\
\hline Retrosternal chest pain (\%) & $5(83.3)$ & $21(75.0)$ & $42(91.3)$ & 0.663 & 0.532 & 0.055 \\
\hline Dyspnoea (\%) & $1(16.7)$ & $4(14.3)$ & $3(6.5)$ & 0.880 & 0.378 & 0.267 \\
\hline $\begin{array}{l}\text { Cardiac arrest, pulmonary } \\
\text { oedema, cardiogenic shock (\%) }\end{array}$ & $0(0.0)$ & $5(17.9)$ & $6(13.0)$ & 0.261 & 0.347 & 0.568 \\
\hline Cardiac rupture (\%) & $0(0.0)$ & $1(3.6)$ & $1(2.2)$ & 0.638 & 0.715 & 0.718 \\
\hline Pneumonia (\%) & $2(33.3)$ & $3(10.7)$ & $10(21.7)$ & 0.155 & 0.488 & 0.268 \\
\hline Rhythm disturbances & $1(16.7)$ & $2(7.1)$ & $3(6.5)$ & 0.453 & 0.378 & 0.917 \\
\hline In-hospital mortality (\%) & $0(0.0)$ & $1(3.6)$ & $1(2.2)$ & 0.638 & 0.715 & 0.718 \\
\hline 1-year mortality (\%) & $3(50.0)$ & $3(10.7)$ & $3(6.5)$ & 0.021 & 0.0017 & 0.522 \\
\hline 3-year mortality (\%) & $5(83.3)$ & $5(17.9)$ & $5(10.9)$ & $<0.0001$ & $<0.0001$ & 0.393 \\
\hline 5-year mortality (\%) & $6(100.0)$ & $7(25.0)$ & $7(15.2)$ & 0.0006 & $<0.0001$ & 0.2964 \\
\hline
\end{tabular}

${ }^{\star}$ No atherosclerotic changes in coronary arteries - coronary arteries without any atherosclerotic lesions. ${ }^{* \star}$ linsignificant stenoses - presence of atherosclerotic lesions in the coronary arteries, which do not cause haemodynamically significant stenoses. ${ }^{* * *}$ Typical for takotsubo prolongation of QT and QTC is observed a few (3-5) days from the onset of symptoms takotsubo. ${ }^{* * * *}$ Troponin (significant increase) troponin value above the upper limit of normal.

graphic and clinical data, parameters from diagnostic tests performed in 3 takotsubo groups is shown in the table (Table I).

The average BMI value within the whole tested takotsubo group $(n=80)$ was $25.8 \mathrm{~kg} / \mathrm{m}^{2}$, and the median was $25.7 \mathrm{~kg} / \mathrm{m}^{2}$.

Patients with TS and $\mathrm{BMI}<18.5 \mathrm{~kg} / \mathrm{m}^{2}$ were older than patients assigned to groups II and III and they less frequently presented risk factors such as hypertension, hypercholesterolemia and positive family history of coronary artery disease. However, these patients smoked cigarettes more often and suffered from chronic obstructive pulmonary disease (COPD), depressive and anxiety disorders, as well as cancer.

In comparison to the other groups, in the group with $\mathrm{BMI}<18.5 \mathrm{~kg} / \mathrm{m}^{2}$, higher values of morphological parameters were found, as well as lower concentrations of troponin, creatine kinase, C-reactive protein (CRP) and lipid fractions.

Retrosternal pain was the main symptom of TS reported in each group. ECG usually showed ST el- evation, including all patients with low body mass. Coronarography performed in patients with TS typically showed the presence of insignificant sclerotic lesions in coronary arteries, most frequently reported within the group with low BMI. Ventriculography and echocardiography performed in all TS patients showed contractility disorders within the scope of the left ventricular apex, with the average ejection fraction being slightly higher in the group with $\mathrm{BMI}<18.5 \mathrm{~kg} / \mathrm{m}^{2}$.

Comparison with the other groups showed that serious complications (sudden cardiac arrest, shock, pulmonary oedema, myocardial rupture) did not occur in the group with BMI $<18.5 \mathrm{~kg} / \mathrm{m}^{2}$. The highest annual and 3-year mortality was reported in the group with $\mathrm{BMI}<18.5$ $\mathrm{kg} / \mathrm{m}^{2}$, whereas after 5 years of follow-up all patients with low BMI were no longer alive (Table I, Figure 2). In group III, the mortality of overweight patients $\left(25 \geq \mathrm{BMI}<30 \mathrm{~kg} / \mathrm{m}^{2}\right)$ was $8.3 \%$, and in obese patients (BMI $\geq 30 \mathrm{~kg} / \mathrm{m}^{2}$ ) it was $20.0 \%$. Body mass index over $25 \mathrm{~kg} / \mathrm{m}^{2}$ (overweight and 


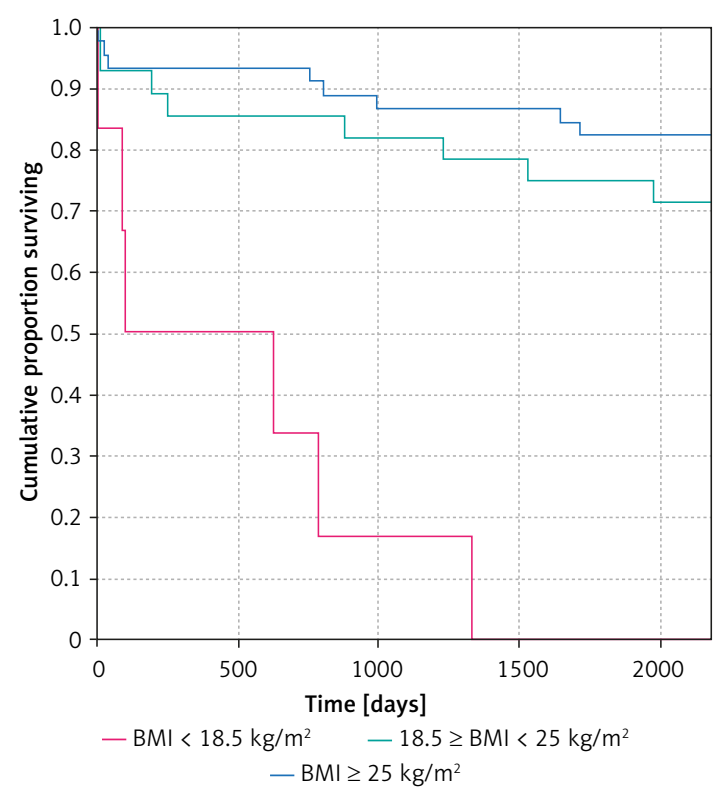

Figure 2. Kaplan-Meier survival curves in patients diagnosed with TS $(n=80)$

obese) was present in $57.5 \%$ of the population studied.

Multivariate analysis showed that risk factors associated with death during the 5-year follow-up period include low estimated glomerular filtration rate (eGFR), low BMI, low left ventricular ejection fraction, low total cholesterol levels and higher haemoglobin concentration (Table II).

\section{Discussion}

Obesity is considered to be a cardiovascular risk factor and simultaneously a factor which significantly increases the risk of complications subsequent to invasive procedures and surgical interventions. For decades it was believed that obesity worsens the prognosis among patients, but recent publications report a trend known as "the obesity paradox". It appears that it may resemble the "cholesterol paradox" [9]. Multiple clinical trials devoted to cardiovascular diseases prove that after several years of observations the greatest mortality was observed among patients with low body mass or proper body mass, and the best prognosis was reported among overweight people $[10,11]$.

Takotsubo syndrome is a mysterious disease entity with its pathomechanism, prognostic, as well as predictive factors remaining not entirely known as it was recently stressed in the consensus documents on Takotsubo (acute 'Stress') cardiomyopathy [12, 13]. O’Rourke et al. [14] very recently have provided mechanisms to explain the syndrome of Takotsubo on the basis of Safar's description of abnormalities of blood flow to the myocardium that occur independently of coronary narrowing [15]. These findings were supported by the Women Ischemia Syndrome Evaluation (WISE) study results $[16,17]$. However, in this study of only 50 females, age ( $\times 10$ years), history of hypertension, history of diabetes, BMI $(\times 10)$, and aortic systolic pressure $(\times 10 \mathrm{~mm} \mathrm{Hg})$ contributed only about $24 \%$ of the variance in coronary flow reserve. In addition, mean BMI was $30.3 \pm 6.9$ $\mathrm{kg} / \mathrm{m}^{2}$ [16] and $72 \%$ had BMI over $25 \mathrm{~kg} / \mathrm{m}^{2}$ [17]. What also remains unknown is the significance of nutrition disorders in the aetiology and the course of stress cardiomyopathy. Takotsubo syndrome is diagnosed not only in people with low body mass, as there are known cases of people suffering from anorexia, but also in obese patients [18-20]. On average, obese patients with TS constitute between $10-20 \%$ of the whole group [21, 22].

In our previous publication, low BMI proved to be a significant death risk factor during the 3-year observation of patients with TS [7], which prompted us to perform additional analyses in longer follow-up [7]. In recently published papers the BMI value is mainly described as the average value characterising the takotsubo group, or it is used to distinguish the group of obese patients $[6,23]$. Desai et al. [24] stated that obese patients with TS revealed a higher risk of severe complications during the final stage of the disease (sudden cardiac arrest, cardiogenic shock, respiratory failure, necessity to implement devices providing left ventricular hemodynamic support), whereas in-hospital mortality was similar to values observed in the group of patients who were not obese. Surprisingly, in-hospital mortality of the patients with the lowest BMI was much lower than that of patients with

Table II. Multivariate analysis of risk factors of death in takotsubo $(n=80)$

\begin{tabular}{|c|c|c|c|c|}
\hline Parameter & Odds ratio & $\mathrm{OR}-95 \% \mathrm{Cl}$ & $\mathrm{OR}+95 \% \mathrm{Cl}$ & $P$-value \\
\hline eGFR & 0.928 & 0.887 & 0.972 & 0.001 \\
\hline BMI & 0.768 & 0.599 & 0.985 & 0.038 \\
\hline $\mathrm{EF}$ & 0.791 & 0.648 & 0.966 & 0.021 \\
\hline Total cholesterol & 0.958 & 0.924 & 0.993 & 0.018 \\
\hline $\mathrm{Hb}$ & 2.724 & 1.171 & 6.340 & 0.020 \\
\hline
\end{tabular}


acute heart failure, but 1-year mortality was significantly higher than in much older patients with acute heart failure [25]. A study by Shiomura et al. [26] focused on factors posing an influence on the quick/delayed improvement in the left ventricular contractile function (LV) in TS; as far as multivariate analysis is concerned $\mathrm{BMI}<20 \mathrm{~kg} / \mathrm{m}^{2}$ proved to a significant independent prognostic factor for quickly regaining LV contractility.

The prognosis for patients with TS is similar to the prognosis for patients with NSTEMI [5]. Due to considerably limited literature directly concerning the influence that BMI has on prognosis among patients with TS, the results obtained in this study have been related to patients with acute coronary syndromes. Patients with TS are less frequently reported to have an excessive body mass. In this study the average BMI value in patients with TS was $25.8 \mathrm{~kg} / \mathrm{m}^{2}$. In other work, the average BMI value reported in groups of patients with TS was even lower: $21.4 \mathrm{~kg} / \mathrm{m}^{2}$ in the study by Shiomura et al. [26]. The average BMI in patients with acute coronary syndromes was $27.3 \mathrm{~kg} / \mathrm{m}^{2}$ in the study by Moscarella et al. [27] and in the meta-analysis performed by Lamelas et al. [28].

In the present study overweight patients constitute the biggest group (45\%), people with normal body weight represent $35 \%, 12.5 \%$ of patients from the tested group were obese, while $7.5 \%$ of patients were underweight. Joyce et al. [29] reported that $51 \%$ of patients were overweight, $30 \%$ had normal body weight, and $19 \%$ people were obese. Similarly, in the study by Moscarella et al. [27], overweight patients amounted to nearly half (49.4\%) of the group with NSTEMI, obese patients - 22.4\% and people with normal BMI - 28.2\%.

This paper focuses mainly on results obtained during the observational study in patients with low body mass $\left(\mathrm{BMI}<18.5 \mathrm{~kg} / \mathrm{m}^{2}\right)$. Despite the fact that the early prognosis within this group is very good, since none of the patients died during the acute stage of the disease, the long-term prognosis is truly devastating. After 1 year, mortality in this group reached $15 \%$, and after 5 years it was $100 \%$. Patients with $\mathrm{BMI}<18.5 \mathrm{~kg} / \mathrm{m}^{2}$ were 9 years older than the remaining patients, which is the result of lower body weight in older patients. Undoubtedly, $100 \%$ mortality in this group of patients was also related to age. However, in a multivariate analysis, older age did not increase the risk of death as opposed to BMI. Even though the lowest mortality after 5 years was reported in overweight patients (15.2\%), this value remains higher than in patients with acute coronary syndromes observed during a comparable follow-up period. Moscarella et al. [27] stated that after a 5 -year follow-up period $9.5 \%$ of overweight patients were dead, slightly more patients with BMI
$<25-13.7 \%$ and the smallest number of obese patients with STEMI - 6.3\%. Joyce et al. [29] noted similar results obtained during a 5-year follow-up of patients after STEMI, as $13.6 \%$ of patients who were underweight or had normal body weight, and $9.1 \%$ of overweight and obese patients died.

The best 5-year prognosis for patients with TS and excessive body mass described in this study also confirms the so-called "obesity paradox" within the group of patients with TS. However, the fatal prognosis in underweight patients reveals a considerable prognostic significance of the BMI within this group of patients, which requires further observational studies in takotsubo groups, with special attention paid to the body mass index.

The greatest limitation related to this study lies in its retrospective character along with a small group of patients suffering from TS. The long-term study based on the PESEL database enabled us to obtain the information on patients' dates of death, but the particular causes of death remain unknown.

In conclusion, the majority of typical cardiovascular risk factors are less frequently observed in patients with TS and low body mass. Early prognosis for patients with low BMI suffering from TS is good, but the 5-year follow-up is associated with very high (100\%) mortality of these patients. Long-term observation reveals that the best prognosis concerns overweight patients $(25 \geq \mathrm{BMI}$ $<30 \mathrm{~kg} / \mathrm{m}^{2}$ ).

\section{Acknowledgments}

We would like to thank Dr Pawet Drozdowski, Dr Jerzy Bychowski and Dr Romuald Krynicki for providing the medical documentation of patients.

\section{Conflict of interest}

The authors declare no conflict of interest.

\section{References}

1. Lyon AR, Bossone E, Schneider B, et al. Current state of knowledge on Takotsubo syndrome: a Position Statement from the Taskforce on Takotsubo Syndrome of the Heart Failure Association of the European Society of Cardiology. Eur J Heart Fail 2016; 18: 8-27.

2. Templin C, Ghadri JR, Diekmann J, et al. Clinical features and outcomes of Takotsubo (stress) cardiomyopathy. N Engl J Med 2015; 373: 929-38.

3. Ghadri JR, Wittstein IS, Prasad A, et al. International Expert Consensus Document on Takotsubo Syndrome (Part I): clinical characteristics, diagnostic criteria, and pathophysiology. Eur Heart J 2018; 39: 2032-46.

4. Sato H, Tateishi H, Uchida T, et al. Tako-tsubo-like left ventricular dysfunction due to multivessel coronary spasm. In: Clinical aspect of myocardial injury: from ischemia to heart failure. Kodama K, Haze K, Hori M (eds). Kagakuhyoronsha Publishing, Tokyo 1990; 56-64.

5. Ghadri JR, Wittstein IS, Prasad A, et al. International Expert Consensus Document on Takotsubo Syndrome 
(Part II): diagnostic workup, outcome, and management. Eur Heart J 2018; 39: 2047-62.

6. Zalewska-Adamiec M, Bachorzewska-Gajewska H, Tomaszuk-Kazberuk A, et al. Takotsubo cardiomyopathy: serious early complications and two-year mortality a 101 case study. Neth Heart J 2016; 24: 511-9.

7. Zalewska-Adamiec M, Małyszko J, Bachórzewska-Gajewska $\mathrm{H}$, et al. Takotsubo syndrome and chronic kidney disease: a deadly duet in long-term follow-up. Pol Arch Intern Med 2018; 128: 518-23.

8. Scantlebury DC, Prasad A. Diagnosis of Takotsubo cardiomyopathy. Circ J 2014; 78: 2129-39.

9. Budzyński J, Tojek K, Wustrau B, et al. The "cholesterol paradox" among inpatients - retrospective analysis of medical documentation. Arch Med Sci Atheroscler Dis 2018; 3: e46-57.

10. Neeland IJ, Das SR, Simon DN, et al. The obesity paradox, extreme obesity, and long-term outcomes in older adults with ST-segment elevation myocardial infarction: results from the NCDR. Eur Heart I Qual Care Clin Outcomes 2017; 3: 183-91.

11. Tomaszuk-Kazberuk A, Kożuch M, Małyszko J, et al. Do overweight patients have a better five years prognosis after an acute myocardial infarction treated with coronary intervention? Kardiol Pol 2012; 70: 686-93.

12. Ghadri JR, Wittstein IS, Prasad A, et al. International Expert Consensus Document on Takotsubo syndrome (Part I): clinical characteristics, diagnostic criteria, and pathophysiology. Eur Heart J 2018; 39: 2032-46.

13. Ghadri JR, Wittstein IS, Prasad A, et al. International Expert Consensus Document on Takotsubo syndrome (Part II): diagnostic workup, outcome, and management. Eur Heart J 2018; 39: 2047-62.

14. O'Rourke MF, Namasivayam M, Adji A. Takotsubo cardiomyopathy: an extreme in the cardiovascular continuum? J Hypertens 2019; 37: 501-3.

15. Thomas F, Pannier B, Danchin N, Safar ME. Wave reflections in hypertension: role of sex, metabolic, and ethnic factors. J Hypertens 2019; 37: 555-62.

16. Nichols WW, Denardo SJ, Davidson JB, Huo T, Bairey Merz CN, Pepine CJ. Association of aortic stiffness and wave reflections with coronary flow reserve in women without obstructive coronary artery disease: an ancillary study from the National Heart, Lung, and Blood Institute-sponsored Women's Ischemia Syndrome Evaluation (WISE). Am Heart J 2015; 170: 1243-54.

17. Nichols WW, Denardo SJ, Johnson BD, Sharaf BL, Bairey Merz CN, Pepine CJ. Increased wave reflection and ejection duration in women with chest pain and nonobstructive coronary artery disease: ancillary study from the Women's Ischemia Syndrome Evaluation. J Hypertens 2013; 31: 1447-54.

18. Rotondi F, Manganelli F, Lanzillo T, et al. Tako-tsubo cardiomyopathy complicated by recurrent torsade de pointes in a patient with anorexia nervosa. Intern Med 2010; 49: 1133-7.

19. Shimizu K, Ogura H, Wasa M, et al. Refractory hypoglycemia and subsequent cardiogenic shock in starvation and refeeding: report of three cases. Nutrition 2014; 30: 1090-2.

20. Viegas F, Viegas C, França E, et al. Takotsubo syndrome as a cause of false acute abdomen in the early postoperative period after bariatric surgery-a report of two cases. Obes Surg 2016; 26: 2547-51.

21. Yayehd K, N'da NW, Belle L, et al. Management of Takotsubo cardiomyopathy in non-academic hospitals in France: The Observational French SyndromEs of Tako
Tsubo (OFSETT) study. Arch Cardiovasc Dis 2016; 109: 4-12.

22. Pelliccia F, Parodi G, Greco C, et al. Comorbidities frequency in Takotsubo syndrome: an international collaborative systematic review including 1109 patients. Am J Med 2015; 128: 654.e11-9.

23. Ando K, Sukekawa H, Takahata A, et al. Renal dysfunction indicative of outcomes in hospitalized patients with takotsubo syndrome. Eur Heart J Acute Cardiovasc Care 2018; 7: 723-31.

24. Desai R, Singh S, Baikpour M, et al. Does obesity affect the outcomes in takotsubo cardiomyopathy? Analysis of the Nationwide Inpatient Sample database, 2010-2014. Clin Cardiol 2018; 41: 1028-34.

25. Arundel C, Sheriff $\mathrm{H}$, Bearden DM, et al. Discharge home health services referral and 30-day all-cause readmission in older adults with heart failure. Arch Med Sci 2018; 14: 995-1002.

26. Shiomura R, Nakamura S, Takano H, et al. Impact of brain natriuretic peptide, calcium channel blockers, and body mass index on recovery time from left ventricular systolic dysfunction in patients with takotsubo cardiomyopathy. Am J Cardiol 2015; 116: 515-9.

27. Moscarella E, Spitaleri G, Brugaletta S, et al. Impact of body mass index on 5 -year clinical outcomes in patients with ST-segment elevation myocardial infarction after everolimus-eluting or bare-metal stent implantation. Am J Cardiol 2017; 120: 1460-6.

28. Lamelas P, Schwalm JD, Quazi I, et al. Effect of body mass index on clinical events after acute coronary syndromes. Am J Cardiol 2017; 120: 1453-9.

29. Joyce E, Hoogslag GE, Kamperidis V, et al. Relationship between myocardial function, body mass index, and outcome after ST-segment-elevation myocardial infarction. Circ Cardiovasc Imaging 2017; 10: pii: e005670. 